\title{
First record of the genus Diplotaxis Kirby, 1837 (Coleoptera, Scarabaeidae, Diplotaxini) in South America
}

\author{
Iván Andrés Mendoza, Sandy García-Atencia
}

Universidad del Atlántico, Facultad de Ciencias Básicas, Departamento de Biología, Grupo de Investigación Biodiversidad del Caribe colombiano, Km.7 antigua vía a Puerto Colombia, Barranquilla, Atlántico, Colombia.

Corresponding author: Iván Andrés Mendoza, iamendoza@mail.uniatlantico.edu.co

\begin{abstract}
The genus Diplotaxis Kirby, 1837 is composed of around 200 species reported from Canada to Panama. The species are most abundantly found in Mexico and the United States. This study reports for the first time the presence of Diplotaxis poropyge Bates, 1887 in Colombia. The individuals are from the departments of Atlántico and Bolívar in the Caribbean region of the country. With this discovery, we update the distribution of the genus to include South America.
\end{abstract}

\section{Key words}

Colombia, crop lands, Melolonthinae, new report, scarab beetle, Tropical dry forest.

Academic editor: Rafael Benzi Braga | Received 6 March 2019 | Accepted 17 April 2019 | Published 24 May 2019

Citation: Mendoza IA, García-Atencia S (2019) First record of the genus Diplotaxis Kirby, 1837 (Coleoptera, Scarabaeidae, Diplotaxini) in South America. Check List 15 (3): 435-439. https://doi.org/10.15560/15.3.435

\section{Introduction}

Diplotaxis Kirby, 1837 is the second most diverse genus of the tribe Diplotaxini worldwide with 241 known species (Evans and Smith 2009, Delgado 2011, Delgado and Mora-Aguilar 2012). They occur from Canada to Panama and the West Indies (Vaurie 1958), and the major representation is in Mexico and the southwestern United States, with 183 and 108 species, respectively (Vaurie 1960).

In South America, there are no distribution records of Diplotaxis species, and the only members of Diplotaxini present in the north of South America are in the genus Liogenys Guérin-Méneville, 1831. According to Vaurie (1958), Diplotaxis and some species of Liogenys are very similar, and Liogenys are distinguished from Diplotaxis by the follow combination of characters: pygidium proportionately larger, also longer than wide; hind coxal plate at center extended farther posteriorly; sutural interval of the elytra narrowed before the apex, the narrow part being somewhat elevated; the hind tibiae flatter, with a sharp, often carinate, not rather rounded inner edge, and the subapical callosity of the elytra situated farther from the margin and nearer the suture (Vaurie 1958). Otherwise, adults of Diplotaxis can be distinguished by their small or medium size $(6-12 \mathrm{~mm})$, black or tawny color, lack of striking sexual dimorphism, and by the follow combination of characters: absence of visible sutures between the propygidium and the fifth ventral segment, sixth ventral segment short, and in the small, rather round or elliptical, but not elongate or triangular pygidium that is entirely exposed by the elytra (Vaurie 1958).

The genus Liogenys is the equivalent of Diplotaxis in its widespread distribution for South America. In fact, the two genera complement each other geographically. While Liogenys is distributed from Panama to southern 

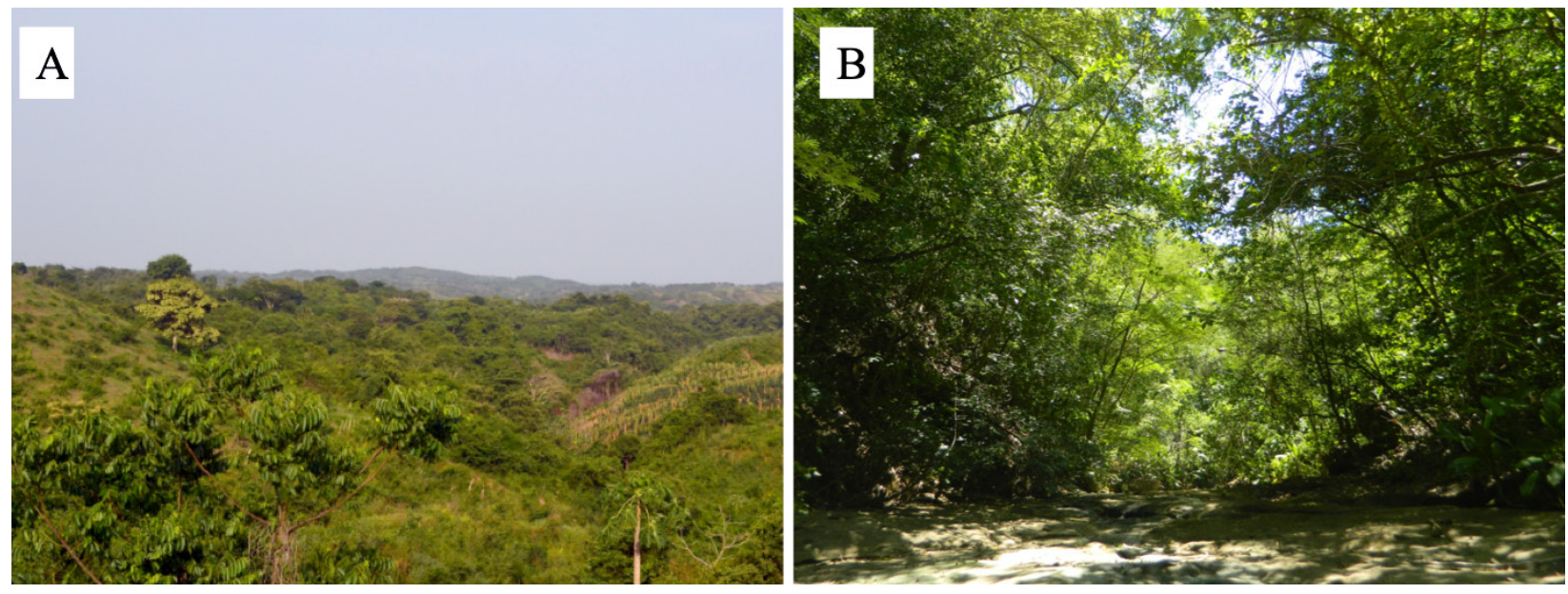

Figure 1. Habitats where Diplotaxis poropyge was collected. A. Reserva La Montaña, Usiacurí, Atlántico. B. Reserva La Flecha, San Jacinto, Bolívar.

Chile and Argentina (Cherman et al. 2017), Diplotaxis reaches the southern limits of its range in Panama with two species (Diplotaxis poropyge Bates, 1887 and Diplotaxis zeteki Vaurie, 1958) (Vaurie 1958).

Within the genus Diplotaxis, D. poropyge is the species with the widest distribution range. It is distributed from Mexico to the south of Panama (Vaurie 1958, 1960). The genus has never been reported from Colombia. However, the presence of Liogenys quadridens (Fabricius, 1798) in the Colombian Caribbean region is well documented (Restrepo-Giraldo et al. 2003, Pardo-Locarno et al. 2012, García-Atencia and Martínez-Hernández 2015, García-Atencia et al. 2015)

In this paper, we record the presence of the genus Diplotaxis in Colombia with new distribution records of Diplotaxis poropyge in the Colombian Caribbean region.

\section{Methods}

The individuals were collected in 2 localities of the Colombian Caribbean region: Reserva La Montaña (RLM) and Reserva La Flecha (RLF).

Reserva La Montaña (Fig. 1A) has an area of 47 ha of tropical dry forest and is located in the Usiacurí municipality, Atlántico department $\left(10^{\circ} 46^{\prime} 02^{\prime \prime} \mathrm{N}, 075^{\circ} 02^{\prime} 34^{\prime \prime} \mathrm{W}\right)$. The forest fragment has an approximate altitude of $220 \mathrm{~m}$ a.s.l., with average annual precipitation and temperature of $1161 \mathrm{~mm}$ and $27^{\circ} \mathrm{C}$, respectively (García-Atencia et al. 2015). The most common plants species include Spondias mombin L., Crescentia cujete L., Pseudobombax septenatum (Jacq.) Dugand, Anacardium excelsum L., Parinari pachyphylla Rusby, Justicia bracteosa (Mildbr.) Leonard, Malvaviscus arboreus Dill. ex Cav., Myrmecodendron costarriscense Britt. and Rose, Petiveria alliiaceae L., Cordia alba (Jacq.) Roem. \& Schult, Mangifera indica L., Guazuma ulmifolia Lam., Pereskia quisqueyana (Ekman) Alain, Bursera simaruba (L.) Sarg., and Hura crepitans L. (García-Atencia et al. 2015).

Reserva La Flecha (Fig. 1B) is located in Palenquito, San Jacinto, Bolívar department (09 $51^{\prime} 12^{\prime \prime} \mathrm{N}, 075^{\circ} 10^{\prime} 41^{\prime \prime}$
W). The area belongs to Montes de Maria subregion and correspond to tropical dry forest (Castaño-Uribe 1999). The forest has an extension of 149ha and an altitude between 350 and $510 \mathrm{~m}$ a.s.l. The average annual precipitation is $1972 \mathrm{~mm}$ and the average annual temperature of $25{ }^{\circ} \mathrm{C}$ (Castaño-Uribe 1999). The most predominant plant species are Aspidosperma polyneuron Müll.Arg., Bursera simaruba (L.) Sarg., Hura crepitans L., Terminalia amazónica (J.F. Gmel.) Exell, Quadrella odoratissima (Jacq.) Hutch., Pseudobombax septenatum (Jacq.) Dugand, Uribea tamarindoides Dugand and Romero, Enterolobium cyclocarpum (Jacq.) Griseb., and Spondias mombin Jacq.

Sampling was performed with white- and ultravioletlight traps. The specimens were examined and identified by observation of external morphological structures and of the male genitalia. The taxonomic identification of the material was made with keys and descriptions proposed by Vaurie (1958). The specimens examined were deposited in the entomological collection of the Museo de Colecciones Biológicas Universidad del Atlántico Región Caribe (UARC), Barranquilla, Colombia.

The photograph of the specimens was taken using a Leica M125 stereomicroscope coupled to a Leica MC170 HD digital camera, using the software Leica Application Suite (LAS) version 4.6 and the construction of the final image was made with the software CombineZP v. 1.0.

The distribution map was prepared with Geographic Information System QGIS "Madeira” (v. 3.4.4, https://qgis. org/es/site/). Previous records of the distribution of the species were taken from Vaurie (1958) and Pacheco-Flores et al. (2008). Records without geographic coordinates were georeferenced to their locality using the geographic database GeoNames (http://www.geonames.org/).

\section{Results}

\section{Diplotaxis poropyge Bates, 1887}

Figure $2 \mathrm{~A}-\mathrm{C}$

Synonym. Diplotaxis subrugosa Moser 1918: 297 


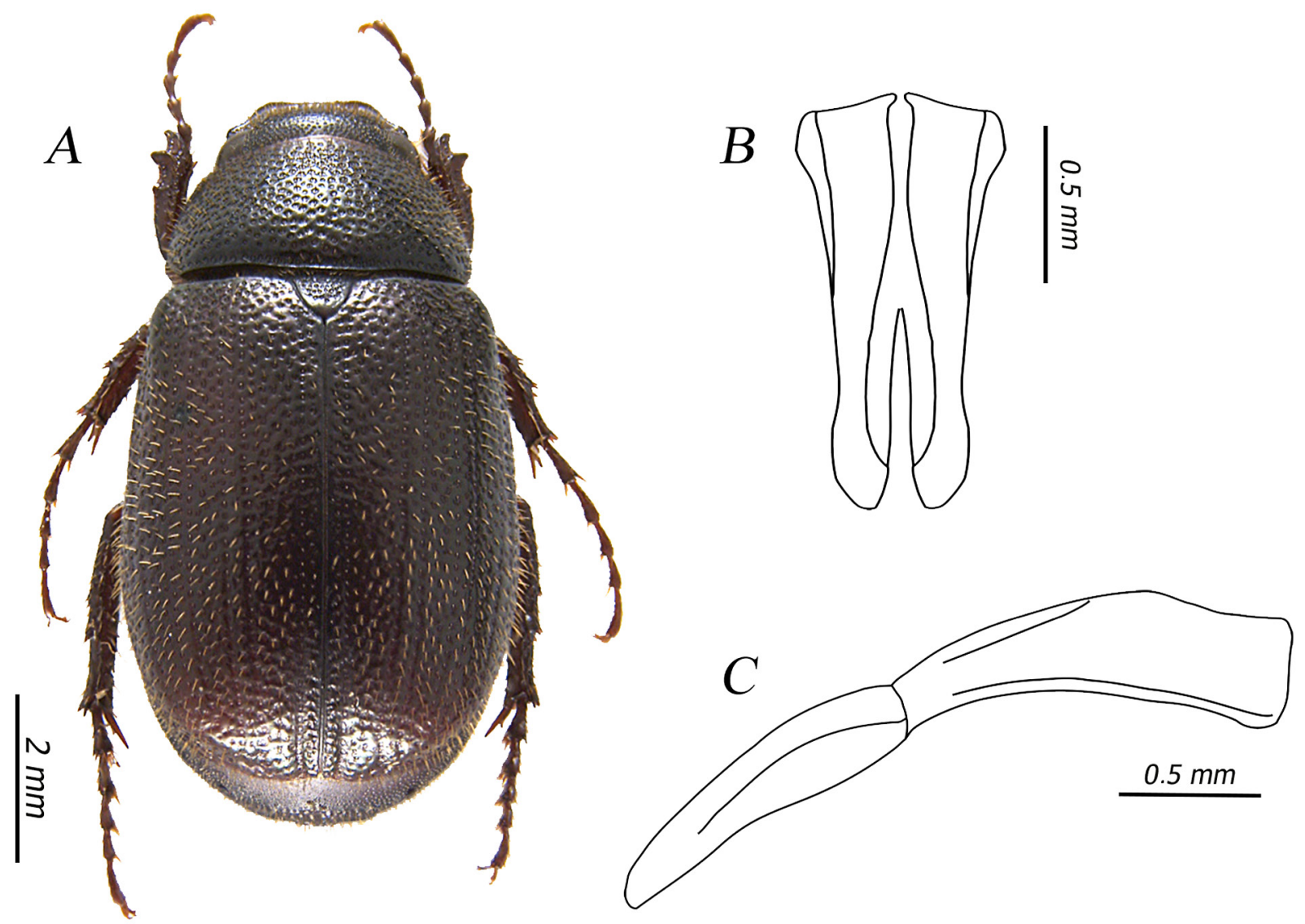

Figure 2. Diplotaxis poropyge. A. Habitus dorsal. B. Caudal view of parameres. C. Lateral view of parameres.

New country record. COLOMBIA • 414 specimens; Atlántico, Usiacurí, Reserva La Montaña; $10^{\circ} 46^{\prime} 02^{\prime \prime} \mathrm{N}$, 07502'34" W; 220 m a.s.1.; 09-13 Mar. 2013; Sandy García-Atencia leg.; tropical dry forest; white- and UV-light traps; UARC-E 01L • 315 specimens; same collection data as for preceding; 08-11 Apr. 2013; cassava and corn cropland; UARC-E 02L • 220 specimens; Bolívar, San Jacinto, Reserva La Flecha; 0951'9" N, 075¹0'32" W; 324 m a.s.l.; 30 Apr. 2017; Iván Mendoza leg.; tropical dry forest; white- and UV-light traps; UARC-E 03L • 120 specimens; same collection data as for preceding; 16-19 Mar. 2018; UARC-E 04L • 98 specimens; same collection data as for preceding; 12-15 Jun. 2018; UARC-E 05L.

Identification. The specimens were identified using descriptions provided by Vaurie (1958). The determination of the species was reached with the help of the specialist Jhon César Neita from the Instituto de Investigación de Recursos Biológicos Alexander von Humboldt (IAvH, Boyacá, Colombia). The new specimens were compared with specimens deposited in the collection of the Instituto de Ecología, A.C. (INECOL, Xalapa, Mexico), with the help of the specialist Eder Mora-Aguilar.

The adults of $D$. poropyge were recognized by the following combination of characters: setae short, unequal in length on elytra, present in interval punctures of elytra, virtually absent from strial punctures, sometimes narrow intervals with longer hairs than broad intervals, abdomen with presence of chitinous ridge, occasionally absent. Within the 8 species belong to the group puberula, $D$. poropyge is more closely linked to $D$. puberula LeConte, 1863, D. subrugata Moser, 1918, and D. hirsuta Vaurie, 1958 because they have a larger labrum and noticeably large mandibles, but $D$. poropyge differs from all species of the group in the absence of setae on the punctures of the elytral striae (Vaurie 1958).

Geographical distribution. Diplotaxis poropyge is known from Costa Rica, Guatemala, El Salvador, Honduras, Mexico, Nicaragua, and Panama. This is the first record of this genus and species from Colombia and from northern South America (Fig. 3).

Remarks. The Diplotaxis species exhibit nocturnal habits and these are easily attracted to light traps. Their food habits are phytophagous, and they are not considered such as pests of plants of economic importance.

The altitude found in both areas is similar to the altitudes recorded in other places where $D$. poropyge has been collected, such as the Mexican tropical dry forests (Vaurie 1958, Reyes-Novelo and Morón 2005, PachecoFlores et al. 2008).

\section{Discussion}

The genus Diplotaxis has been reported from Canada to the southern parts of Panama without records from Colombia. Diplotaxis poropyge has been recorded from 


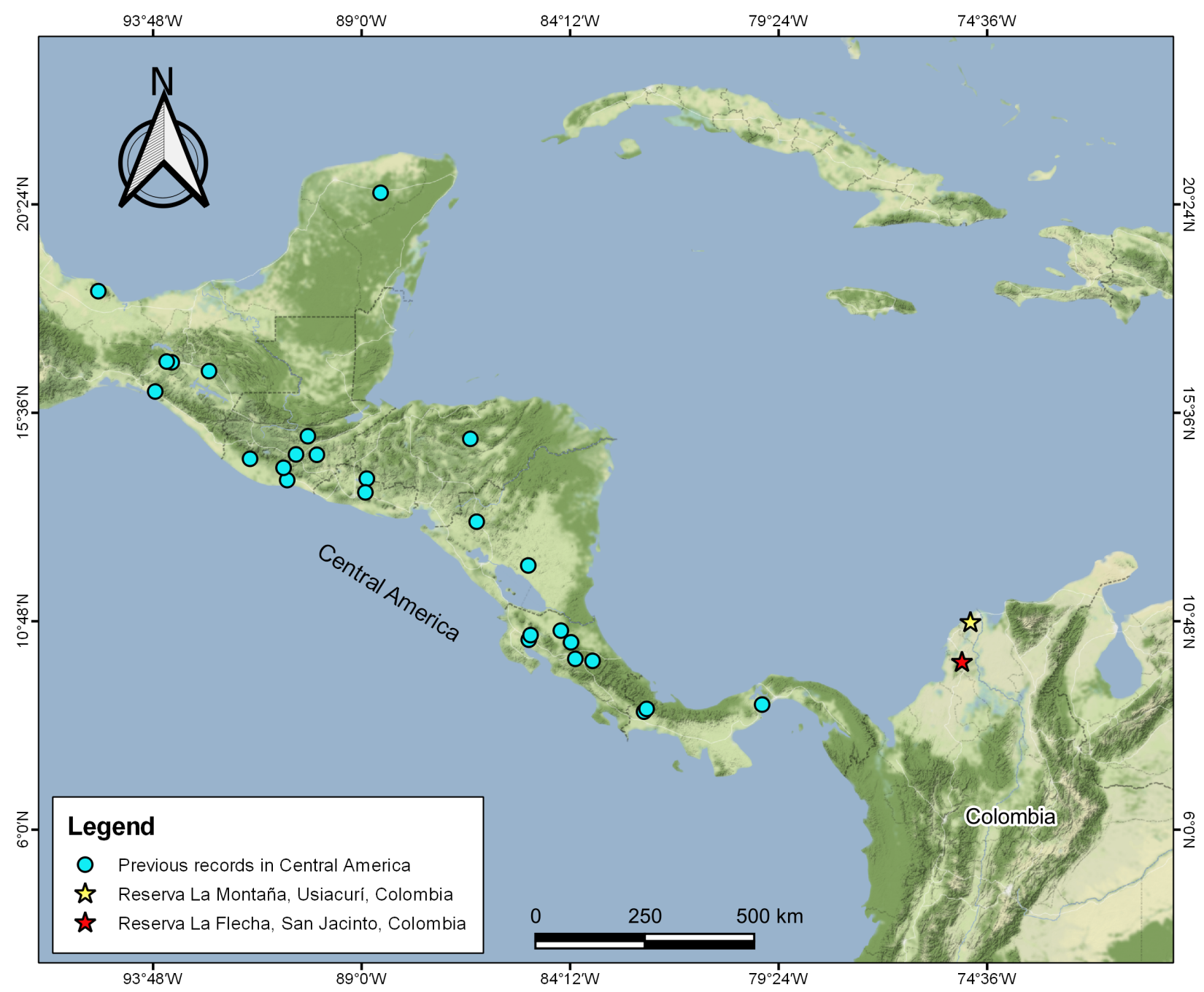

Figure 3. Map of known distribution of Diplotaxis poropyge. Blue circles are previous records. Stars are new records.

Central America and now, for the first time, from South America. However, the populations founded in tropical dry forest from RLM and RLF are numerous. The new records are based on 729 individuals captured in RLM and 438 individuals captured in RLF during rainy season.

According to García-Atencia and Martínez-Hernández (2015) and García-Atencia et al. (2015) in RLM, there are populations of Liogenys quadridens in crop lands and forest and they are in sympatry with Diplotaxis. These genera are very similar, but this sympatry represents an overlap on the periphery of their ranges (Vaurie 1958). According to Vaurie (1958), Diplotaxis and Liogenys evolved independently in North America and South America (respectively), and that sympatry probably is the result of secondary expansion. This suggests that the dispersion may be due to the reduction of environmental filters and the niche breadth in the limits of the distribution of species of these genera. On the other hand, is possibly that this sympatry has existed for a long time and the lack of sampling in the Colombian Caribbean region kept this sympatry hidden. Regardless, the distribution of Diplotaxis has been underestimated. Therefore, we report that the range of $D$. poropyge, the most widely distributed species of the genus, reaches the tropical dry forest of the north of Colombia.

\section{Acknowledgements}

We thank to the Universidad del Atlántico for its support of this project, as well as Dr Jhon César Neita from the Instituto Alexander von Humboldt (IAvH) and Eder Mora-Aguilar from the Instituto de Ecología A.C. (INECOL).

\section{Authors' Contributions}

IAM collected the specimens, conducted processing of genital structures, produced the map, took the photographs and co-wrote the manuscript. SGA collected the specimens, drew the genitalia, and co-wrote the manuscript.

\section{References}

Castaño-Uribe CS (1999) Serranías de Colombia. Banco de Occidente I/M Editores. Cali, 329 pp.

Cherman MA, Mise KM, Morón MA, Vaz-de-Mello FZ, Almeida LM (2017) A taxonomic revision of Liogenys occurring in Brazil with an interactive key and remarks on New World Diplotaxini 
(Coleoptera, Melolonthidae). ZooKeys 699: 1-120. https://doi.org 10.3897/zookeys.699.12031

Delgado L (2011) A new species of the genus Diplotaxis Kirby, 1837 (Coleoptera: Scarabaeidae: Melolonthinae: Diplotaxini) from northeastern Mexico. The Coleopterists Bulletin 65 (2): 189-191. https:// doi.org/10.1649/072.065.0221

Delgado L, Mora-Aguilar EF (2012) Diplotaxis multicarinata (Coleoptera: Scarabaeidae), a new species from a relict forest in Oaxaca, Mexico. Florida Entomologist 95 (2): 285-289. https://doi.org/10. 1653/024.095.0207

Evans A, Smith A (2009) An electronic checklist of the New World chafers (Coleoptera: Scarabaeidae: Melolonthinae) version 3 . 353 pp. http://museum.unl.edu/research/entomology/SSSA/NWMelo-v3.pdf. Accessed on: 2018-05-28.

García-Atencia S, Martínez-Hernández N (2015) Escarabajos fitófagos (Coleoptera: Scarabaeidae) del departamento del Atlántico, Colombia. Acta Zoológica Mexicana (n.s.) 31 (1): 89-96.

García-Atencia S, Martínez-Hernández N, Pardo-Locarno LC (2015) Escarabajos fitófagos (Coleoptera: Scarabaeidae) en un fragmento de bosque seco tropical del departamento del Atlántico, Colombia. Revista Mexicana de Biodiversidad 86: 754-763. https://doi. org/10.1016/j.rmb.2015.07.009
Pacheco-Flores C, Castro-Ramírez AE, Morón MA, Gómez B (2008) Fauna de escarabajos melolóntidos (Coleoptera: Scarabaeoidea) en el municipio de Villa Flores, Chiapas, México. Acta Zoológica Mexicana (n.s.) 24 (1): 139-168.

Pardo-Locarno LC, González JC, Pérez CR, Yepes F, Fernández C (2012) Escarabajos de importancia agrícola (Coleoptera: Melolonthidae) en la región Caribe colombiana: registros y propuestas de manejo. Boletín del Museo Entomológico Francisco Luis Gallejo 4 (4): 7-23.

Restrepo-Giraldo H, Morón MA, Vallejo F, Pardo-Locarno LC, LópezÁvila A (2003) Catálogo de Coleoptera Melolonthidae (Scarabaeidae Pleurosticti) de Colombia. Folia Entomológica Mexicana 42 (2): 239-263.

Reyes-Novelo E, Morón MA (2005) Fauna de Coleoptera Melolonthidae y Passalidae de Tzucacab y Conkal, Yucatán, México. Acta Zoológica Mexicana (n.s.) 21 (2): 15-49.

Vaurie P (1958) A revision of the genus Diplotaxis (Coleoptera, Scarabaeidae, Melolonthinae). Part 1. Bulletin of the American Museum of Natural History 115 (5): 263-396.

Vaurie P (1960) A revision of the genus Diplotaxis (Coleoptera, Scarabaeidae, Melolonthinae). Part 2. Bulletin of the American Museum of Natural History 120 (2): 161-434 